\title{
Social economic costs of COPD in Extremadura (Spain): an observational study
}

This article was published in the following Dove Press journal: International journal of COPD

\author{
María Merino' \\ Renata Villoro' \\ Álvaro Hidalgo-Vega ${ }^{1,2}$ \\ Concepción Carmona ${ }^{3}$ \\ 'Weber Foundation, Majadahonda, \\ Madrid, Spain; ${ }^{2}$ Department of \\ Economic Analysis and Finances, \\ University of Castilla-La Mancha, \\ Toledo, Spain; ${ }^{3}$ Extremadura Health \\ Service, Mérida, Badajoz, Spain
}

Purpose: COPD has been associated with a high number of comorbidities and a relatively high level of health care resource utilization. This study aimed to estimate the social economic impact of COPD in the autonomous community of Extremadura (Spain) in 2015.

Patients and methods: This is a retrospective observational study carried out using a representative sample of patients diagnosed with COPD in Extremadura. Sociodemographic data, data on health care resource utilization, formal and informal care received by the patients, and loss of labor productivity in the last 12 months were collected through an electronic data collection platform. Direct health care costs were estimated using the bottom-up approach, costs of informal care were assessed using the substitution method, and labor productivity losses were calculated using the human capital method.

Results: A sample of 386 patients was obtained (mean age: $71.8 \pm 10.3$ years, males: $76.2 \%$ ). The results show an average annual cost per patient of 3,077 euros. Direct health care costs represented $43.8 \%$ (1,645 euros), direct non-health care costs amounted to $38.3 \%$ (1,440 euros), and labor productivity losses represented $17.9 \%$ (672 euros) of the average annual cost. The total annual cost of patients with COPD in Extremadura reached 36.2 million euros in 2015.

Conclusion: COPD poses a significant burden for the health care system and the society of Extremadura. The implementation of preventive and control measures could result in a substantial reduction in the economic impact.

Keywords: COPD, social costs, health care resource utilization, informal care, labor productivity losses

\section{Introduction}

Although there are no recent definitive data on the prevalence of COPD in the adult population in Spain, the latest study, published in 2009, suggested a prevalence rate of $10.2 \%$ in the population between 40 and 80 years of age. ${ }^{1}$ In Extremadura, one of Spain's 17 autonomous communities, the prevalence rate of COPD has been estimated at $4.9 \%$ among adults aged $40-69$ years in the year $2000^{2}$ and at $4.4 \%$ among the population aged $\geq 15$ years in $2012 .^{3,4}$ However, these rates may underestimate the real prevalence, for two reasons: first, they were calculated using the old European Respiratory Society criteria to define $\mathrm{COPD}^{5}$ and second because the findings are based on data from already diagnosed patients, while it is known that up to $73 \%$ of people with COPD have not been diagnosed yet. ${ }^{6}$

It is well known that COPD entails high economic costs associated to the consumption of health care resources, as well as a significant loss of health-related quality of life. ${ }^{7-10}$ However, the economic burden of COPD has not been assessed in Spain or any of its 17 geographical autonomous communities. The economic burden includes not only direct costs associated with the consumption of health resources but also labor productivity
Correspondence: María Merino Fundación Weber, Calle Norias, 123, 2822I Majadahonda, Madrid, Spain Tel +34 9l 6393824

Fax +34 9l 6346643

Email maria.merino@weber.org.es
International Journal of COPD 20I8:13 250I-25/4 Dovepress f $y$ in 0 http://dx,doi.org/10.21471COPD.S167357 (c) (1) (5) 2018 Merino et al. This work is published and licensed by Dove Medical Press Limited. The full terms of this license are available at https://www.dovepress.com/terms.php cc) ${ }_{\mathrm{BY}} \mathrm{NC}$ and incorporate the Creative Commons Attribution - Non Commercial (unported, v3.0) License (http://creativecommons.org/licenses/by-nc/3.0/). By accessing the work you hereby accept the Terms. Non-commercial uses of the work are permitted without any further permission from Dove Medical Press Limited, provided the work is properly attributed. For permission for commercial use of this work, please see paragraphs 4.2 and 5 of our Terms (https://www.dovepress.com/terms.php). 
losses of patients derived both from poor health and from time spent on medical visits or hospital stays associated with COPD, as well as the costs of professional and informal care (the latter defined as unpaid care that is provided by family members or friends) that the patients may need. Additionally, the total economic burden should also consider intangible costs related to the negative impact that COPD has on the quality of life of both the patients and their caregivers, even if difficult to estimate in monetary terms. ${ }^{11}$

The objective of this study was to estimate the economic burden associated to COPD in 2015 in the autonomous community of Extremadura (Spain), including three main cost categories: 1) direct health care costs (DHC), 2) direct non-health care costs (DNHC), including both professional and informal care, and 3) indirect costs (IC) derived from the patient's labor productivity losses.

\section{Patient and methods}

\section{Subject population}

The Extremadura Health Service includes eight different health areas. Health areas are geographical divisions with a relatively decentralized management of primary care services in each area, as is the case across all Spanish autonomous communities. The eight health areas of Extremadura are in turn subdivided into a total of 114 Basic health areas. According to official data from the Extremadura Health System, there were a total of 9,622 people diagnosed with COPD in Extremadura in April 2015 (79.9\% males, 79.3\% $\geq 65$ years), spread across its eight health areas. Therefore, our population universe was 9,622 individuals.

\section{Study design}

A retrospective cross-sectional observational study was designed, with a probabilistic sampling stratified by Health Area in order to obtain a representative sample of patients with COPD in Extremadura. In the first stage, a randomized sample representative of the adult population diagnosed with COPD in Extremadura ( $n=386,95 \%$ confidence level, 5\% sampling error) was calculated based on the prevalence of COPD in the population aged $\geq 18$ years in Extremadura. In the second stage, two age group quotas ( $<65$ years of age and $\geq 65$ ) as well as quotas by gender within those age groups were established within the sample in order to represent different age and gender groups of prevalence in each of the eight health areas of Extremadura. We then randomly selected 18 Basic health areas distributed across the eight health areas of Extremadura, proportionately to the number of Basic health areas in each Health Area. The number of patients and age/gender quotas to enroll in each Basic Health Zone were assigned to each Basic Health Zone in such a way that the theoretical sample was proportionally distributed across health areas, and within each Health Area they were proportionally distributed across age and gender of the population with COPD residing in each of the health areas.

Inclusion criteria were the following: people diagnosed with COPD according to the WHO classification criteria ${ }^{12}$ at least 12 months before their inclusion in the study, being 18 years of age or older, residents of Extremadura whose electronic medical records were available for 12 months prior to the collection of data, and patients who provided their informed consent to participate in the study in accordance with local regulations. Patients with any limitation that according to the researchers' best judgement could affect the reliability of their answers were excluded (eg, patients without knowledge of the Spanish language, or patients with any evident cognitive impairment). Patients who had participated in any clinical trial in 12 months prior to the collection of data and pregnant women were also excluded.

A total of 18 previously trained researchers participated in data collection, one in each of the selected 18 Basic health areas. Researchers received a randomly ordered list of all the patients diagnosed with COPD who resided in their corresponding Basic Health Zone. The patients' name, telephone number, and address were included in the list and disclosed to the field researchers but were never available to the authors of this manuscript. Researchers contacted patients over the telephone following the order in their list. Whenever a patient was not available on the telephone, researchers contacted the next patient on the list. After telephone contact was established, researchers verified with the patient that inclusion/exclusion criteria were met and, if the criteria were met, asked the patient to meet them in person either in the patient's home or in their primary care center, whichever was preferred by the patient. Patients were recruited this way until all age and gender quotas were completed for each Basic Health Zone.

Fieldwork was carried out between July 10 and November 11, 2015, and included one single visit per patient, with retrospective data collection for 12 months prior to the date of the visit. Data were collected through three different sources, including two closed and structured electronic case report forms (CRFs) that were completed by the researchers using an electronic tablet, and one microdata 
database directly provided by the Extremadura Health System. The first CRF, called "the patient's CRF," collected information directly from the patient and included details on home respiratory therapies, institutionalization, professional care, informal care, and loss of labor productivity related to COPD in the last 12 months. The second CRF, called "the researcher's CRF," collected information directly provided by the patient's electronic clinical records and included clinical data related to COPD in the last 12 months. Finally, microdata provided by the Extremadura Health System included data on medication and consumption of other health care resources in the last 12 months. Information was also collected on patients' quality of life using the EuroQol-5D-5L questionnaire (general quality of life at the time of the visit) and the St George's Respiratory Questionnaire for COPD patients (specific quality of life of patients with airway obstruction). Patient quality of life results will be presented in another publication.
The phases of data collection are summarized in Figure 1. Prior to data collection, patients were informed about the study objectives and data confidentiality. They provided their written informed consent to participate in the study and to release information, according to the Spanish legislation, and permission to perform the study was obtained from the Clinical Research Ethics Committee of the University Hospital Infanta Cristina (Badajoz).

\section{Study variables}

\section{Assessment of COPD severity}

The electronic clinical records of a portion of the patients did not specify the severity of their COPD. In these cases, three complementary sources of information were used for the construction of a "severity" variable according to the Global Initiative for Chronic Obstructive Lung Disease (GOLD) scale. ${ }^{13}$ First, the GOLD classification of the patient was used, as long as it was included in their clinical history.

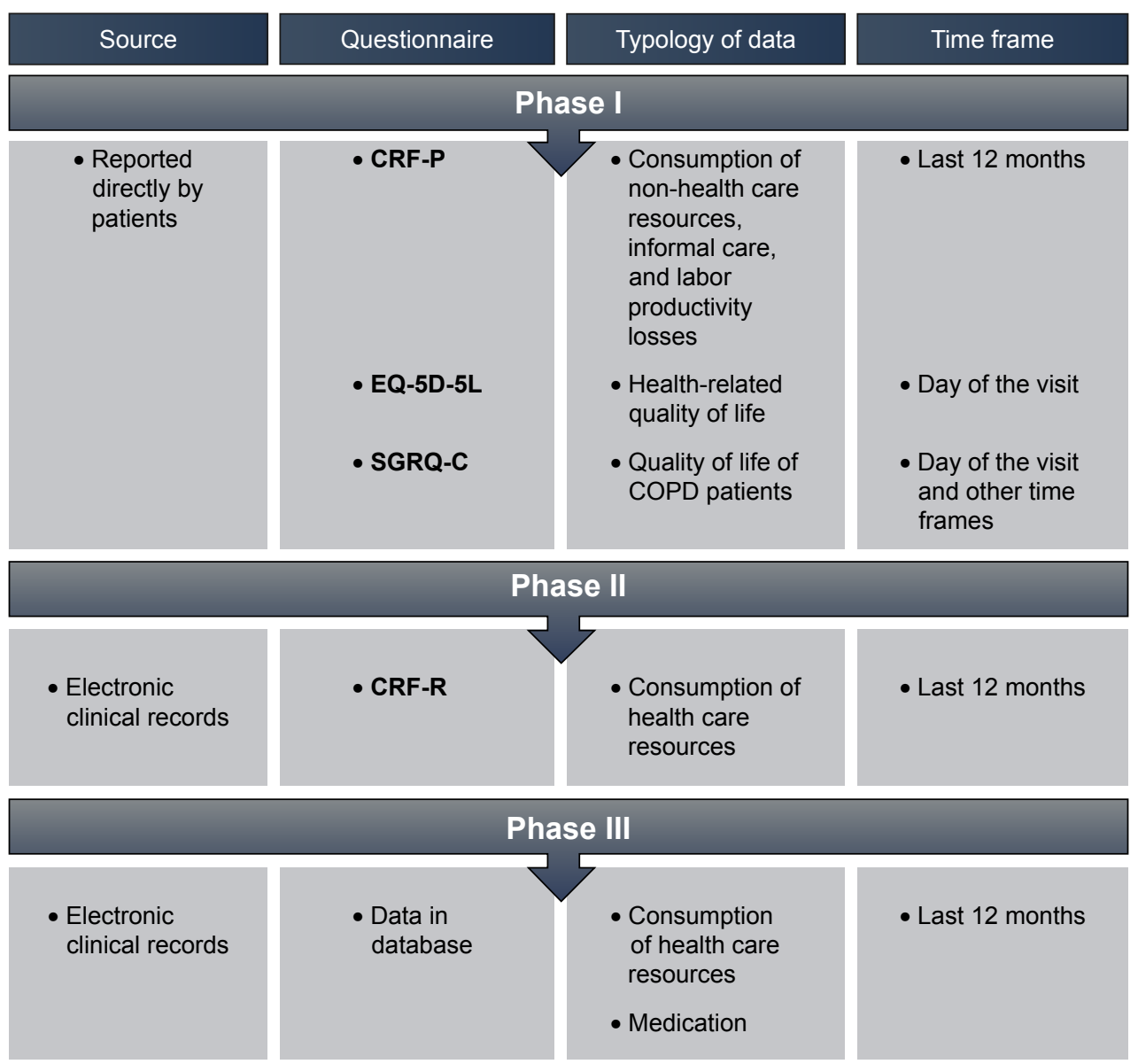

Figure I Phases in data collection.

Abbreviations: CRF-R, researcher's case report forms; CRF-P, patient's case report forms; SGRQ-C, St George's Respiratory Questionnaire for COPD; EQ-5D-5L, EuroQol-5D-5L questionnaire. 
Second, in the absence of the GOLD classification, severity was calculated using the most recent forced expiratory volume (FEV)\% data. Third, if both the GOLD scale and the $\mathrm{FEV} \%$ data were missing from the clinical record, then the free description made by the doctor in the patient's clinical history coinciding with the GOLD scale was used. Finally, if all of the previous data were lacking, an "unknown/not available" severity degree was assigned to that particular patient.

\section{Costs methodology}

Following traditional cost-of-illness studies' methodology, ${ }^{14-16}$ we estimated DHC (those borne by the National Health System), DNHC (out of pocket expenditures borne by families, other public institutions [such as social services], and cost equivalence of the time devoted to caregiving), and IC (cost equivalence of the patients' productivity losses). Costs were estimated from a societal perspective, that is, including all available direct costs and IC associated with COPD in 12 months prior to the visit. All direct costs were estimated using the bottom-up costing method, ${ }^{17}$ except for the costs of informal care, for which the substitution method was used. In order to minimize recall bias related to informal care, we asked for the average hours per day devoted by caregivers to administering medication and helping in daily tasks (such as getting dressed, personal hygiene, and cooking), and average hours per month devoted to accompanying the patient to medical visits and tests, collecting medication from pharmacy, and administrative or legal tasks, and then multiplied daily care hours by 365 and monthly care hours by 12 , and added them in order to obtain yearly hours. Labor productivity losses were estimated using the human capital approach. The reference year for all costs was 2015. Costs with reference years prior to 2015 were updated using the Spanish Medical Consumer Price Index (CPI) for health care costs and the Spanish General CPI for other costs. ${ }^{18}$

\section{Costs}

DHC included medication linked to the respiratory system; medical visits to the pulmonology specialist; medical tests; outpatient and hospital emergencies; the use of an ambulance, both for emergency medical transportation and for on-site care; hospital admissions; and home oxygen therapy. DHC were calculated by multiplying the resources used by their unit prices.

DNHC included use of social services such as stay in nursing homes and attendance at (non-health care) day centers; professional care (defined as care provided by a professional caregiver, such as a paid domestic aid); and informal care (defined as care provided by family members or friends without remuneration) provided both by the main caregiver (the person who spent the most time caring for the patient) and by all other caregivers. The cost of informal care was estimated using the replacement cost approach, which values the time spent on caregiving at the wage rate or market price of a close substitute. In this case, we used the minimum hourly wage of a household employee (because of its nonspecialized care character). The rest of the DNHC was calculated by multiplying the resources used by their unit prices.

IC included labor productivity lost by the patient in the form of absenteeism from work due to medical visits, sick leave, and hospitalizations, as well as early retirement and unemployment directly related to COPD (according to the patient's perception). Labor productivity losses were measured using the human capital method, by which work time lost as a result of illness is valued at the market wage. Therefore, IC were estimated as the average wages forgone by the patient due to COPD.

The costs of medication consumed by the patient were provided directly by the Extremadura Health System in the form of microdata. Unit prices related to other health care resources and their source are presented in Table S1.

The total cost (TC) associated to COPD included the sum of DHC, DNHC, and IC. The cost per patient per year refers to the average cost of COPD per patient per year in Extremadura. The total annual cost refers to the cost of COPD in Extremadura in 1 year.

\section{Statistical analysis}

Descriptive statistics (number of valid cases, mean, and SD) were calculated for all continuous variables, and frequencies and percentages were calculated for categorical variables. Additionally, cost comparison was carried out by COPD severity, gender, and age group. Nonparametric techniques were used (Mann-Whitney $U$ and Kruskal-Wallis $U$ tests) due to the absence of a normal distribution. Statistical significance was set at $p<0.05$. Statistical analyses were performed using IBM SPSS Statistics V22.0 (IBM Corporation, Armonk, NY, USA).

\section{Results}

A valid sample of 386 patients meeting inclusion criteria was obtained ( $76.2 \%$ males, mean age $71.8 \pm 10.3$ years). The sample was representative of patients diagnosed with COPD 
in Extremadura in terms of gender and age across the eight sanitary areas. Tables 1 and 2 show the sociodemographic and clinical characteristics of the sample, respectively.

\section{Utilization of health care resources}

The most frequently performed medical tests were blood tests $(0.6 \pm 1.4$ times on average), chest X-ray $(0.6 \pm 1)$, gasometry $(0.5 \pm 1.2)$, and spirometry without bronchodilator testing $(0.3 \pm 0.6)$. The average number of pulmonology visits was $0.8( \pm 1.3)$ per patient per year. Averages of $0.4( \pm 1)$ visits to the hospital emergency room and $0.3( \pm 0.7)$ to the emergency room at the health center were recorded, per patient per year. The emergency ambulance was used an average of $0.3( \pm 1.1)$ times per patient, of which $0.28( \pm 1.1)$ times corresponded to unassisted emergency transportation mode. Overall, $15.4 \%$ of the patients used home oxygen therapy; oxygen concentrator was the main type $(59.5 \%)$, followed by liquid oxygen (18.9\%). The mean time of daily use of this therapy was $14.5( \pm 5.7)$ hours. The average number of hospital admissions per patient was $0.2( \pm 0.5)$. Within the medication related to COPD, agents against obstructive respiratory tract diseases were the most consumed (91.5\%), followed by antihistamines for systemic use (5.8\%), and oral preparations $(2.7 \%)$ (Table 3$)$.

Table I Sociodemographic characteristics of the sample

\begin{tabular}{|c|c|}
\hline Sociodemographic characteristics & Total \\
\hline Gender (\% males) & 76.2 \\
\hline Age in years $($ mean $\pm S D)$ & $71.8 \pm 10.3$ \\
\hline \multicolumn{2}{|l|}{ Age group (\%) } \\
\hline$<65$ years & 20.7 \\
\hline$\geq 65$ years & 79.3 \\
\hline \multicolumn{2}{|l|}{ Smoking history (\%) } \\
\hline Current smoker & 16.7 \\
\hline Ex-smoker & 69.6 \\
\hline Never smoked & 13.7 \\
\hline \multicolumn{2}{|l|}{ Daily cigarettes (mean $\pm S D$ ) } \\
\hline Smokers & $14.1 \pm 10.3$ \\
\hline Ex-smoker & $27.3 \pm 16.4$ \\
\hline \multicolumn{2}{|l|}{ Education level (\%) } \\
\hline Does not know how to read or write & 6.0 \\
\hline No education & 33.9 \\
\hline Primary education & 35.9 \\
\hline Secondary education & 18.5 \\
\hline University education & 5.7 \\
\hline \multicolumn{2}{|l|}{ Employment status (\%) } \\
\hline Early retirement/retired & 78.9 \\
\hline Actively working & 7.9 \\
\hline Domestic work & 7.1 \\
\hline Unemployed & 3.4 \\
\hline Permanent leave & 1.6 \\
\hline Temporary leave & I.I \\
\hline
\end{tabular}

Abbreviation: SD, standard deviation.
Table 2 Clinical characteristics of the sample

\begin{tabular}{|c|c|}
\hline Clinical characteristics & Total \\
\hline $\mathrm{FEV}_{1} / \mathrm{FVC}(\text { mean } \pm \mathrm{SD})^{\mathrm{a}}$ & $60.3 \pm 18.7$ \\
\hline $\mathrm{FEV}_{1} \%(\text { mean } \pm \mathrm{SD})^{\mathrm{b}}$ & $66.7 \pm 22.3$ \\
\hline \multicolumn{2}{|l|}{ COPD severity (\%) } \\
\hline GOLD I & 10.9 \\
\hline GOLD II & 20.5 \\
\hline GOLD III & 9.1 \\
\hline GOLD IV & 1.3 \\
\hline Unknown/not available & 58.3 \\
\hline Exacerbations in the last 12 months (\% yes) ${ }^{c}$ & 36.7 \\
\hline $\begin{array}{l}\text { Number of exacerbations in the last } 12 \text { months } \\
(\text { mean } \pm S D)^{d}\end{array}$ & $0.6 \pm 1.2$ \\
\hline Number of comorbidities (mean \pm SD) & $7.8 \pm 4.7$ \\
\hline \multicolumn{2}{|l|}{ Main comorbidities (\%) } \\
\hline Cardiovascular comorbidity ${ }^{e}$ & 60.6 \\
\hline Dyslipidemia/lipid metabolism disorder & 41.5 \\
\hline Noncomplicated hypertension & 38.3 \\
\hline Diabetes mellitus (type I + type 2) & 27.2 \\
\hline Arthritis/arthrosis & 20.0 \\
\hline Cancer/malignancy & 14.8 \\
\hline Hypertension with target organ involvement & 13.0 \\
\hline Anemia & 6.7 \\
\hline Depression & 6.2 \\
\hline Asthma & 6.0 \\
\hline Osteoporosis & 3.9 \\
\hline $\mathrm{BMI}(\text { mean } \pm \mathrm{SD})^{\mathrm{f}}$ & $30.0 \pm 5.0$ \\
\hline \multicolumn{2}{|l|}{ BMI classification according to WHO (\%) } \\
\hline Insufficient weight & 0.8 \\
\hline Normal weight & 3.4 \\
\hline Overweight & 16.1 \\
\hline Obesity & 18.4 \\
\hline Unknown/not available & 61.4 \\
\hline
\end{tabular}

Notes: a Number of valid cases: 123, number of missing values: 263 . ${ }^{b}$ Number of valid cases: 140, number of missing values: 246 . ${ }^{c, d}$ Number of valid cases: 215 , number of missing values: 17I. eIncludes cerebrovascular accident/ictus/apoplexy, unspecified cardiac arrhythmia, atherosclerosis or peripheral arterial disease, valvular heart disease, atrial fibrillation/atrial flutter, acute myocardial infarction, heart failure, cardiac ischemia with angina, cardiac ischemia without angina, transient cerebral ischemia, other cardiac diseases, other cardiovascular diseases, other cardiovascular signs/symptoms, and paroxysmal tachycardia. ${ }^{\dagger}$ Number of valid cases: 149, number of missing values: 237.

Abbreviations: SD, standard deviation; BMI, body mass index; WHO, World Health Organization; $\mathrm{FEV}_{1}$, forced expiratory volume in I second; FVC, forced vital capacity; COPD, chronic obstructive pulmonary disease; GOLD, Global Initiative for Chronic Obstructive Lung Disease.

\section{Utilization of non-health care resources}

Overall, $3.8 \%$ of patients were living permanently in a home or residential center. In $21.9 \%$ of these cases, admission was specifically due to COPD. A total of $5.3 \%$ of patients needed professional care at home due to their illness, and received an average of $12.7( \pm 16.1)$ hours of care per week. A total of $17.4 \%$ of the patients received informal care due to their illness. In $63.4 \%$ of these cases there was only one caregiver, while in the remaining $36.6 \%$ there were two or more caregivers. The informal caregiver profile was female $(84.3 \%)$, aged $61.3( \pm 14.2)$, and partner $(44.8 \%)$ or 
Table 3 Utilization of health care resources in the last 12 months

\begin{tabular}{|c|c|c|}
\hline Resource typology & Total & $\begin{array}{l}N \text { (valid }^{\text {cases) }} \\
\text { cas }^{\mathrm{a}}\end{array}$ \\
\hline \multicolumn{3}{|l|}{ Medical tests (mean \pm SD) } \\
\hline Blood analysis & $0.6 \pm 1.4$ & 292 \\
\hline Spirometry with bd test & $0.1 \pm 0.4$ & 280 \\
\hline Spirometry without bd test & $0.3 \pm 0.6$ & 271 \\
\hline Alpha-I antitrypsin & $0.0 \pm 0.2$ & 254 \\
\hline Chest X-ray & $0.6 \pm 1.0$ & 299 \\
\hline CAT & $0.1 \pm 0.3$ & 289 \\
\hline Gasometry & $0.5 \pm 1.2$ & 276 \\
\hline Pulmonology visits (mean \pm SD) & $0.8 \pm 1.3$ & 386 \\
\hline \multicolumn{3}{|l|}{ Visits to the emergency room (mean $\pm S D$ ) } \\
\hline Health center emergencies & $0.3 \pm 0.7$ & 284 \\
\hline Hospital emergencies & $0.4 \pm 1.0$ & 302 \\
\hline \multicolumn{3}{|l|}{ Use of ambulance (mean $\pm S D$ ) } \\
\hline Total times & $0.30 \pm 1.1$ & 381 \\
\hline $\begin{array}{l}\text { Times when used as non-assisted } \\
\text { emergency health transport }{ }^{\text {b }}\end{array}$ & $0.28 \pm \mathrm{I} . \mathrm{I}$ & 381 \\
\hline Use of home oxygen therapy (\%) & 15.4 & 386 \\
\hline \multicolumn{3}{|l|}{ Use of home oxygen therapy (only users) (mean \pm SD) ${ }^{c}$} \\
\hline Hours per day & $14.5 \pm 5.7$ & 57 \\
\hline Months (over the past year) & $10.6 \pm 3.2$ & 57 \\
\hline Hospital admissions (mean \pm SD) & $0.2 \pm 0.5$ & 328 \\
\hline Medication consumed (\%) & & 386 \\
\hline ROI nasal preparations & 2.7 & \\
\hline ICS & 2.7 & \\
\hline \multicolumn{3}{|l|}{ respiratory diseases } \\
\hline Short-acting beta agonists & 6.2 & \\
\hline Long-acting beta agonists & 6.9 & \\
\hline Short-acting muscarinic agonists & 3.3 & \\
\hline Long-acting muscarinic receptor antagonists & 32.0 & \\
\hline ICS & 2.9 & \\
\hline Fixed combinations & 31.7 & \\
\hline Leukotriene receptor antagonist & 3.8 & \\
\hline Interleukin inhibitors phosphodiesterase & 3.4 & \\
\hline Methylxanthines & 1.4 & \\
\hline R06 antihistamines for systemic use & 5.8 & \\
\hline Antihistamines for systemic use & 5.8 & \\
\hline
\end{tabular}

Notes: "Valid cases refer to all cases (386), including users of "zero" units, minus missing values. 'As opposed to on-site ambulance services. "Results calculated only for users of home oxygen therapy (59 patients).

Abbreviations: bd, bronchodilator; SD, standard deviation; CAT, computerized axial tomography; ICS, inhaled corticosteroid.

daughter (44.5\%) of the patient. The monthly average hours of informal care amounted to $19( \pm 53)$ hours provided by the main caregiver and to $2.5( \pm 21.9)$ hours provided by other caregivers (Table 4).

\section{Labor productivity losses}

The vast majority of patients (78.9\%) were retired or early retirees at the time of the survey. In $3.7 \%$ of cases, early retirement was due to COPD. Overall, $16.7 \%$ of working
Table 4 Utilization of non-health care resources in the last 12 months

\begin{tabular}{|c|c|c|}
\hline Resource typology & $\begin{array}{l}\text { Total } \\
\text { (\%/mean } \pm \text { SD) }\end{array}$ & $\begin{array}{l}\mathbf{N}(\text { valid } \\
\text { cases) }^{\mathrm{a}}\end{array}$ \\
\hline \multicolumn{3}{|c|}{ Permanent stay in housing or residential center } \\
\hline Yes & 3.8 & 386 \\
\hline Due to COPD & 21.9 & \\
\hline \multicolumn{3}{|l|}{ Attendance at day center } \\
\hline Yes & 0.3 & 372 \\
\hline Due to COPD & 0.0 & \\
\hline \multicolumn{3}{|l|}{ Professional care at home } \\
\hline Due to COPD & 5.3 & 371 \\
\hline $\begin{array}{l}\text { Months over the past year } \\
\text { (only users) }\end{array}$ & $10.8 \pm 3.1$ & 18 \\
\hline Hours of weekly care (only users) ${ }^{b}$ & $12.7 \pm 16.1$ & \\
\hline \multicolumn{3}{|l|}{ Informal caregiving } \\
\hline Due to COPD & 17.5 & 371 \\
\hline $\begin{array}{l}\text { Months over the past year } \\
\text { (only users) }\end{array}$ & $11.0 \pm 2.7$ & \\
\hline \multicolumn{3}{|l|}{ Hours of care per month } \\
\hline Principal caregiver ${ }^{d}$ & $19.0 \pm 53.0$ & 386 \\
\hline Other caregivers & $2.5 \pm 21.9$ & \\
\hline \multicolumn{3}{|l|}{ Number of informal caregivers ${ }^{c}$} \\
\hline One caregiver & 63.4 & 63 \\
\hline Two or more caregivers & 36.6 & \\
\hline \multicolumn{3}{|l|}{ Profile of principal informal caregiver ${ }^{c}$} \\
\hline \multicolumn{3}{|l|}{ Gender } \\
\hline Female & 84.3 & 64 \\
\hline Male & 15.7 & \\
\hline Age (years) & $61.3 \pm 14.2$ & \\
\hline \multicolumn{3}{|l|}{ Relationship with the patient } \\
\hline Spouse/partner & 44.8 & \\
\hline Daughter/son & 44.5 & \\
\hline Other & 10.7 & \\
\hline
\end{tabular}

Notes: aValid cases refer to all cases (386) minus missing values. ${ }^{\circ}$ Results calculated only for users of professional care at home (20 patients). 'Results calculated only for users of informal caregiving (65 patients). ${ }^{\mathrm{d}}$ Censored to a maximum of 8 hours per day.

Abbreviations: SD, standard deviation; COPD, chronic obstructive pulmonary disease.

patients had seen their work affected by COPD, having to be absent from work on occasion due to the disease. In addition, $7.4 \%$ of people engaged in domestic work did not work outside their home because of COPD. Among the patients who were unemployed, $7.7 \%$ considered that they had lost their jobs due to their illness, and $38.5 \%$ perceived having difficulties in accessing a job for the same reason.

\section{Cost estimations}

The average annual cost per patient with COPD in 2015 amounted to $3,757( \pm 6,800)$ euros and was distributed as follows: DHC accounted for $43.8 \%$, DNHC for $38.3 \%$, and IC for $17.9 \%$. The average annual DHC per patient was 1,645 $( \pm 2,240)$ euros; of these, medication accounted for the largest amount (44.5\%), followed by hospital admissions (23.1\%), 
and home oxygen therapy (11.3\%). The annual average DNHC amounted to $1,440( \pm 4,068)$ euros. Most of DNHC corresponded to informal care $(81.9 \%)$, followed by formal care (13.1\%), and residential care (5\%). The IC attributable exclusively to COPD amounted to $672( \pm 3,744)$ euros per patient per year (Table 5).

Table 6 shows the average annual costs per patient according to severity, gender, and age group. The TC and DHC per patient showed statistically significant differences between severity groups $(p<0.05)$, revealing in both cases a progressive rise in cost from the initial stages (I and II) to the most advanced stages (III and IV) of COPD. Regarding DNHC, there were no significant differences between the two initial stages (I and II), although there were significant differences between these two stages and stages III and IV $(p<0.05)$. IC did not show statistically significant differences between the different severity categories. Differences in costs were not statistically significant by gender, although there were differences by age group, with patients aged $\geq 65$ years presenting higher direct costs (both DHC and DNHC) but lower labor productivity losses and lower TC.

As our sample was representative of the Extremadura population, we extrapolated the average costs per patient to the population with COPD in Extremadura. The TC of COPD in Extremadura was 36,152,319 euros per year. Of these, 15.83 million euros corresponded to $\mathrm{DHC}, 13.86$ million euros to DNHC, and 6.47 million euros to IC (Figure 2).

Table 5 Annual average costs per patient (euros 20I5)

\begin{tabular}{|c|c|c|c|c|}
\hline Cost typology & Mean \pm SD & $95 \% \mathrm{Cl}$ & $\%$ of subcategory & $\%$ of $\mathrm{TC}$ \\
\hline Direct health costs & $\mathrm{I}, 645 \pm 2,240$ & $1,42 \mid-1,869$ & 100 & 43.8 \\
\hline Medical tests ${ }^{\mathrm{a}}$ & $47 \pm 121$ & & 2.9 & 1.2 \\
\hline Pulmonology visits & $89 \pm 157$ & & 5.4 & 2.4 \\
\hline Emergency visits ${ }^{\mathrm{b}}$ & $102 \pm 439$ & & 6.2 & 2.7 \\
\hline Use of ambulance ${ }^{b}$ & $108 \pm 433$ & & 6.6 & 2.9 \\
\hline Use of home oxygen therapy ${ }^{c}$ & $187 \pm 459$ & & 11.3 & 5.0 \\
\hline Hospital admissions & $380 \pm 1.387$ & & 23.1 & 10.1 \\
\hline Medication (total) & $732 \pm 626$ & & 44.5 & 19.5 \\
\hline \multicolumn{5}{|l|}{ ROI nasal preparations } \\
\hline ICS & $5 \pm 20$ & & 0.3 & 0.1 \\
\hline \multicolumn{5}{|l|}{ R03 agents against obstructive respiratory diseases } \\
\hline Short-acting beta agonists & $367 \pm 407$ & & 22.3 & 9.8 \\
\hline Long-acting beta agonists & $|3 \pm 5|$ & & 0.8 & 0.3 \\
\hline Short-acting muscarinic agonists & $49 \pm 142$ & & 3.0 & 1.3 \\
\hline Long-acting muscarinic receptor antagonists & $236 \pm 258$ & & 14.4 & 6.3 \\
\hline ICS & $13 \pm 56$ & & 0.8 & 0.3 \\
\hline Fixed combinations & $1 \pm 6$ & & 0.1 & 0.0 \\
\hline Leukotriene receptor antagonist & $28 \pm 133$ & & 1.7 & 0.7 \\
\hline Interleukin inhibitors phosphodiesterase & $5 \pm 15$ & & 0.3 & 0.1 \\
\hline Methylxanthines & $6 \pm 27$ & & 0.3 & 0.1 \\
\hline \multicolumn{5}{|l|}{ R06 antihistamines for systemic use } \\
\hline Antihistamines for systemic use & $9 \pm 29$ & & 0.6 & 0.2 \\
\hline Direct non-health costs & $1,440 \pm 4,068$ & $\mathrm{I}, 033-\mathrm{I}, 847$ & 100 & 38.3 \\
\hline Stay in residential center & $73 \pm 797$ & & 5.0 & 1.9 \\
\hline Attendance at day center & $0.0 \pm 0.0$ & & 0.0 & 0.0 \\
\hline Formal care in home & $189 \pm 1.287$ & & 13.1 & 5.0 \\
\hline Informal care & $\mathrm{I}, \mathrm{I} 79 \pm 3,749$ & & 81.9 & 31.4 \\
\hline Principal caregiver $^{d}$ & $|, 036 \pm 3,05|$ & & 71.9 & 27.6 \\
\hline Other caregivers & $143 \pm 1,333$ & & 10.0 & 3.8 \\
\hline Indirect $\cos \mathrm{t}^{\mathrm{e}}$ & $672 \pm 3,744$ & $298-1,047$ & 100 & 17.9 \\
\hline Total cost/patient/year & $3,757 \pm 6,800$ & $3,077-4,438$ & - & 100 \\
\hline
\end{tabular}

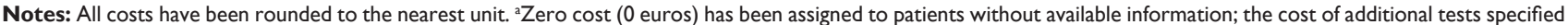
in the CRF-R is included. ' ${ }^{2}$ ero cost ( 0 euros) has been assigned to patients without available information. ${ }^{c}$ The cost has been calculated assuming the use of full months of oxygen therapy; in cases without information on the months of use, the average time of use of the rest of the patients has been assigned. ${ }^{\circ} \mathrm{Cost}$ calculated assuming 8 hours a day of informal care. ${ }^{e}$ All cases were included: zero cost ( 0 euros) has been assigned to patients $>65$ years of age (age of retirement) and to labor productivity losses that were not a consequence of COPD.

Abbreviations: SD, standard deviation; Cl, confidence interval; ICS, inhaled corticosteroid; COPD, chronic obstructive pulmonary disease; CRF-R, researcher's case report forms. 
Table 6 Average annual costs per patient according to severity, gender, and age group (euros 2015)

\begin{tabular}{|c|c|c|c|c|c|}
\hline Subgroups & Valid $\mathbf{N}$ & DHC & DNHC & IC & TC \\
\hline \multicolumn{6}{|c|}{ GOLD severity scale } \\
\hline GOLD I & 41 & $1,246^{*}$ & $\mathrm{I}, 004$ & 550 & $2,800 *$ \\
\hline GOLD II & 79 & $2,123^{*}$ & 1,042 & 1,120 & $4,285^{*}$ \\
\hline GOLD III & 35 & $2,430 *$ & $3,507^{*}$ & 1,905 & $7,842^{*}$ \\
\hline GOLD IVa & 5 & $5,669 *$ & $7,691 *$ & 4,298 & $17,658^{*}$ \\
\hline Unknown ${ }^{\mathrm{b}}$ & 226 & $\mathrm{I}, 334$ & 1,189 & 261 & 2,784 \\
\hline \multicolumn{6}{|l|}{ Gender } \\
\hline Male & 308 & 1,682 & I,456 & 678 & 3,816 \\
\hline Female & 78 & 1,500 & $\mathrm{I}, 376$ & 649 & 3,525 \\
\hline \multicolumn{6}{|l|}{ Age range } \\
\hline$<65$ years & 80 & $1,26 I^{*}$ & $560^{*}$ & $2,650 *$ & $4,47 I^{*}$ \\
\hline$\geq 65$ years & 306 & $\mathrm{I}, 745^{*}$ & $\mathrm{I}, 670^{*}$ & $157^{c, *}$ & $3,57 I^{*}$ \\
\hline Total & 386 & $\mathrm{I}, 645$ & $\mathrm{I}, 440$ & 672 & 3,757 \\
\hline
\end{tabular}

Notes: All costs have been rounded to the nearest unit. ${ }^{a}$ The low number of valid cases in this category suggests caution in the interpretation of its results. ${ }^{b}$ This category was not included in the analysis of differences (Kruskal-Wallis test). 'Corresponds to labor productivity losses in the last 12 months for people up to 65 years of age. *Statistically significant differences $(p<0.05)$ within each type of cost between the categories of each variable.

Abbreviations: DHC, direct health costs; DNHC, direct non-health costs; IC, indirect costs; TC, total cost; GOLD, Global Initiative for Chronic Obstructive Lung Disease.

\section{Discussion}

To our knowledge, this is the first study to estimate the social economic cost of COPD on a representative sample of adult patients in a Spanish autonomous community. Extremadura is only one of the 17 autonomous communities in Spain and gathers only $2.35 \%$ of the total Spanish population. Although this may limit the generalizability of our results to the rest of the country, the ratios of professional, structural, and technological health care resources in Extremadura are in line with average values in Spain, ${ }^{19}$ and the random selection of the Basic health areas where patients were recruited reflects potential differences in diagnostic and therapeutic patterns. Therefore, there is no reason to assume that the use of the resources consumed by the patients and the cost of these resources differ substantially from use and costs elsewhere in Spain. Moreover, the fact that Extremadura is an autonomous community with a relatively old population and a low population density ${ }^{20}$ makes it an optimal population for the development of this study as a pilot experience for future analyses in other autonomous communities that could serve to update national data on COPD economic burden.

Previous studies have estimated that the annual costs of COPD range between 675 and 775 million euros (of 1994) for Spain, including direct, indirect, and intangible costs. ${ }^{21}$ Other Spanish studies focus on the calculation of direct health costs, which range between 911 and 3,238 euros per patient per year. ${ }^{7,9,22-25}$ Despite the broad range of this interval, the studies agree that most DHC correspond to hospitalizations (40\%-45\%), followed by pharmacological costs (35\%-40\%), and visits and diagnostic tests $(15 \%-25 \%))^{7,9,23,24}$ Our results indicate that in Extremadura, the proportion of DHC corresponding to pharmacological costs is slightly higher than these estimates (44.5\%), and that hospital admissions are significantly lower than previous findings (23.1\%).

One of the main strengths of our study is the estimation of the costs of informal care for COPD, as data published on this type of cost are scarce. A study conducted using the Spanish Survey on Disabilities, Personal Autonomy and Dependency (EDAD-08) estimated that $\sim 48 \%$ of patients with COPD received informal care, which was valued between 24,549 and 40,681 euros per patient per year. ${ }^{26}$ These values are higher than our estimates, mainly because the EDAD-08 survey only includes individuals with a declared disability, with a greater need for care, and is not representative of COPD patients. Our results show that informal care accounts for $81.9 \%$ of the DNHC and $31.4 \%$ of the TC, indicating the incapacitating nature of COPD.

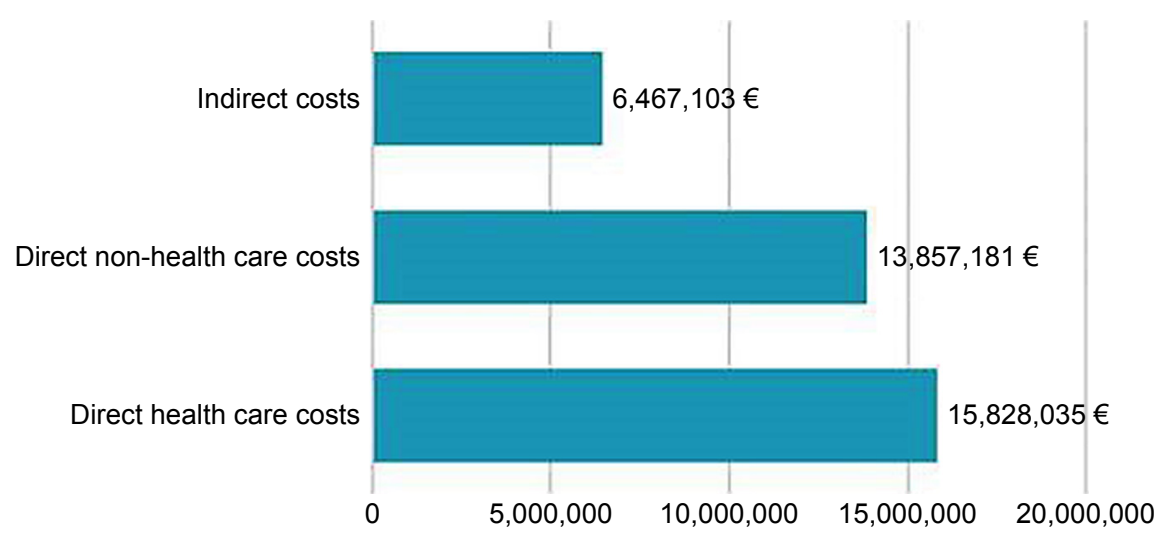

Figure 2 Total annual cost of COPD in Extremadura in 2015 according to cost typology. Abbreviation: COPD, chronic obstructive pulmonary disease. 
Our results on labor productivity lost by patients also shed light on the work disability linked to COPD, representing $17.9 \%$ of the TC.

Previous studies have documented the direct relationship between the level of severity of COPD and the derived costs. ${ }^{7,9,13,23-25,27}$ Our analysis found that patients with the highest COPD severity (classified as GOLD IV) had an average TC six times higher than that of the patients classified as GOLD I (17,658 vs 2,800 euros per year), four times higher than the patients classified as GOLD II (4,285 euros), and twice that of patients classified as GOLD III (7,842 euros). Gender did not account for significant differences in any of the cost categories, while analysis by age groups showed that patients $\geq 65$ years of age incur higher direct costs, which is likely due to complications and/or comorbidities of COPD.

Regarding productivity losses, those of working patients ( $<65$ years of age) accounted for $60 \%$ of their TC. This percentage is higher than that represented by the productivity losses of other chronic diseases, even those that affect younger population groups, such as depression, ${ }^{28}$ diabetes mellitus, ${ }^{29,30}$ HIV-AIDS, ${ }^{31}$ ankylosing spondylitis, ${ }^{32}$ heart failure, ${ }^{33}$ and multiple sclerosis. ${ }^{34}$

This study is not without limitations. First, the severity level of the patient's COPD corresponds to a variable constructed from information provided by the clinical history. However, this information was missing for the majority $(58.3 \%)$ of the participants, for primary care records only collect information on the number of spirometries the patient had in the past 12 months, but do not necessarily provide the results of the spirometries, nor the GOLD classification of the patient. Therefore, the relationship between lung function impairment and costs that is presented in Table 6 may not reflect the actual relationship in the population. Had data been collected from pulmonology services' clinical records, information on lung function impairment would be available for all patients. Second, the use of resources corresponds to resources associated with COPD in the past 12 months but it is possible that a proportion of these resources may not be strictly associated to COPD but to its related comorbidities. Thus, a clear distinction between costs strictly COPD related and costs related to its comorbidities cannot be made from our database, and results show all costs associated with COPD and its comorbidities. Third, working patients (7.9\% of the sample) had to recall lost working hours in the past 12 months due to medical visits, tests, hospitalization, or feeling poorly, while patients on early retirement, temporary or permanent leave due to COPD, had to recall the length of time they had been in that situation. Therefore, results for productivity losses may be subject to some degree of recall bias. Finally, due to the difficulty in estimating in monetary terms the intangible costs associated with COPD - such as the loss of quality of life, and pain and suffering of both patients and informal caregivers - intangible costs were not taken into account in our calculations. The latter, together with the high rate of underdiagnosis of COPD in the general population, might imply that the real socioeconomic impact of COPD in Extremadura exceeds the figures estimated in this study.

\section{Conclusion}

Despite these limitations, this work represents the most complete and realistic economic estimate of the burden of COPD in Extremadura to date and can serve as an example for future cost estimations in other autonomous communities or nationwide, with the aim to enlighten the real magnitude of the socioeconomic impact of COPD in Spain.

In the context of permanent competitive demands due to the scarcity of health care resources, information on economic burden is necessary and important to make informed resource allocation decisions in the areas of prevention, early diagnosis, and management of COPD. Likewise, cost estimations might be valuable for future economic evaluations of new treatments for the disease. In addition, any program, strategy, or health care policy aimed at COPD patients should not overlook the importance of informal care. In brief, estimations of direct costs and IC of COPD might provide valuable information for decision making based on empirical evidence that will favor not only patients but also society in general.

\section{Acknowledgments}

This study was funded by Chiesi España. The authors wish to thank the patients and their caregivers who provided their time to participate in the study. In addition, we would like to thank José Luis Sánchez Chorro for his help in coordinating the data collection.

Likewise, we would like to thank the Collaborative Working Group EPOC-Extremadura who participated in the recruitment and data collection, whose members are listed herein: Susana Alonso García De Vinuesa, Basic Health Area of Mérida - Obispo Paulo; Anastasia Bejarano Cebrián, Basic Health Area of Arroyo de la Luz; Gema Beorlegui Aristu, Basic Health Area of Plasencia - Luis de Toro; José Carlos Domínguez Rodríguez, Basic Health Area of Coria; Lorenzo Fernández Prieto, Basic Health Area of Llerena; Ma Carmen Galán Parra, Basic Health Area of Casas del Castañar; Aurelia 
María García Martínez, Basic Health Area of Don Benito Oeste; Rosa Ma García-Adámez Soto, Basic Health Area of Zalamea de la Serena; $M^{\mathrm{a}}$ Mercedes Guío Carretero, Basic Health Area of Hornachos; Laura Horrillo Murillo, Basic Health Area of Trujillo Urbano; $M^{\mathrm{a}}$ Teresa Laso Martínez, Basic Health Area of Cáceres - Norte; Laura Martín Jurado, Basic Health Area of Oliva de la Frontera; Miguel A Martín de la Nava, Basic Health Area of Zorita; Ma Eugenia Martínez Domínguez, Basic Health Area of Navalmoral de la Mata; Carmen Morillo Pantoja, Basic Health Area of Badajoz - Zona Centro; Olga Ortiz Rodríguez, Basic Health Area of Zafra; Manuela Pardo Amaya, Basic Health Area of Talarrubias; and Ana $\mathrm{M}^{\mathrm{a}}$ Villalba Doblas, Basic Health Area of Badajoz - La Paz.

\section{Author contributions}

$\mathrm{MM}, \mathrm{RV}$, and AHV participated in the conception and design of the study. CC participated in the acquisition of data. MM and RV participated in the analysis and interpretation of data. MM wrote the draft of the manuscript. All authors contributed toward data analysis, drafting and revising the paper and agree to be accountable for all aspects of the work. All authors critically revised the manuscript for important intellectual content and approved the final version to be published.

\section{Disclosure}

The authors report no conflicts of interest in this work.

\section{References}

1. Miravitlles M, Soriano JB, García-Río F, et al. Prevalence of COPD in Spain: impact of undiagnosed COPD on quality of life and daily life activities. Thorax. 2009;64(10):863-868.

2. Sobradillo Peña V, Miravitlles M, Gabriel R, et al. Geographic variations in prevalence and underdiagnosis of COPD: results of the IBERPOC multicentre epidemiological study. Chest. 2000;118(4):981-989.

3. Instituto Nacional de Estadística [webpage on the Internet]. Enfermedades Crónicas. Problemas o enfermedades crónicas o de larga evolución padecidas en los últimos 12 meses y diagnosticadas por un médico en población adulta según sexo y comunidad autónoma. Población de 15 y más años. INE [updated 2012]. Available from: http://www.ine. es/jaxi/Tabla.htm?path=/t15/p419/a2011/p01/10/\&file=01030.px\&L=0. Accessed August 31, 2016.

4. Instituto Nacional de Estadística [webpage on the Internet]. Resultados por Comunidades autónomas. Población residente por fecha, sexo y edad. INE [updated 2012]. Available from: http://www.ine.es/jaxiT3/Tabla. $\mathrm{htm} ? \mathrm{t}=9681 \& \mathrm{~L}=0$. Accessed August 31, 2016.

5. Siafakas NM, Vermeire P, Pride N, et al. Optimal assessment and management of chronic obstructive pulmonary disease (COPD). The European Respiratory Society Task Force. Eur Respir J. 1995;8(8): 1398-1420.

6. Ancochea J, Miravitlles M, García-Río F, et al. Infradiagnóstico de la enfermedad pulmonar obstructiva crónica en mujeres: cuantificación del problema, determinantes y propuestas de acción. Arch Bronconeumol. 2013;49(6):223-229. Spanish.

7. Masa JF, Sobradillo V, Villasante C, et al. Costes de la EPOC en España. Estimación a partir de un estudio epidemiológico poblacional. Arch Bronconeumol. 2004;40(2):72-79. Spanish.
8. Espinosa Mesa N, Perea Herrera R, Vega García SS, et al. Calidad de vida y situación sociosanitaria de los pacientes con EPOC. Med Fam. 2005; 6(3):137-144. Spanish.

9. Miravitlles M, Murio C, Guerrero T, et al. Costs of chronic bronchitis and COPD: a 1-year follow-up study. Chest. 2003;123(3):784-791.

10. Soler JJ, Perpiñá M, Sánchez L, et al. Impacto asistencial hospitalario de la EPOC. Peso específico del paciente con EPOC de alto consumo sanitario. Arch Bronconeumol. 2001;37(9):375-381. Spanish.

11. Akobundu E, Ju J, Blatt L, et al. Cost-of-illness studies: a review of current methods. Pharmacoeconomics. 2006;24(9):869-890.

12. World Health Organization [webpage on the Internet]. COPD management. WHO. Available from: http://www.who.int/respiratory/copd/ management/en/. Accessed February 23, 2017.

13. Global Initiative for Chronic Obstructive Lung Disease [webpage on the Internet]. Global strategy for diagnosis, management, and prevention of COPD - 2016. GOLD. Available from: http://goldcopd.org/globalstrategy-diagnosis-management-prevention-copd-2016/. Accessed February 15, 2017.

14. Drummond M. Cost-of-illness studies: a major headache? Pharmacoeconomics. 1992;2(1):1-4.

15. Hodgson TA. Costs of illness in cost-effectiveness analysis. A review of the methodology. Pharmacoeconomics. 1994;6(6):536-552.

16. Jo C. Cost-of-illness studies: concepts, scopes, and methods. Clin Mol Hepatol. 2014;20(4):327-337.

17. Drummond MF, Sculpher MJ, Claxton K, et al. Methods for the Economic Evaluation of Health Care Programmes. 4th ed. Oxford: Oxford University Press; 2015.

18. Instituto Nacional de Estadística [webpage on the Internet]. Índices nacionales: general y de grupos COICOP. Índices de Precios al Consumo. Base 2011. INE; 2015. Available from: http://www.ine.es/jaxiT3/ Tabla.htm?t=10013\&L=0. Accessed August 10, 2016.

19. Ministerio de Sanidad, Servicios Sociales e Igualdad. Informe Anual del Sistema Nacional de Salud 2016. 2017. Available from: https:// www.msssi.gob.es/estadEstudios/estadisticas/sisInfSanSNS/tablasEstadisticas/InfAnualSNS2016/Informe_Anual_SNS_2016_completo.pdf. Accessed March 21, 2018.

20. Instituto Nacional de Estadística. España en cifras 2016. INE [updated 2016]. Available from: http://www.ine.es/prodyser/espa_cifras/2016/files/ assets/common/downloads/publication.pdf. Accessed May 9, 2017.

21. Ministerio de Sanidad y Política Social. Estrategia En EPOC Del Sistema Nacional de Salud. Ministerio de Sanidad y Política Social; 2009. Available from: http://www.msc.es/organizacion/sns/planCalidadSNS/docs/EstrategiaEPOCSNS.pdf. Accessed August 29, 2016.

22. Grupo de Trabajo de GesEPOC. Guía de Práctica Clínica para el diagnóstico y tratamiento de pacientes con Enfermedad Pulmonar Obstructiva Crónica (EPOC)-Guía Española de la EPOC (GesEPOC). Arch Bronconeumol. 2012;48:2-58. Spanish.

23. García Ruiz A, Fernández Leiva F, Crespo Martos F, et al. Utilización de recursos y costes directos sanitarios de la EPOC en Atención Primaria de Salud (Estudio EPOC-AP). Rev Esp Econ Salud. 2003;2(3):176-181. Spanish.

24. Izquierdo-Alonso JL, de Miguel-Díez J. Economic impact of pulmonary drugs on direct costs of stable chronic obstructive pulmonary disease. COPD. 2004;1(2):215-223.

25. Izquierdo JL. The burden of COPD in Spain: results from the confronting COPD survey. Respir Med. 2003;97(Suppl C):S61-S69.

26. Peña-Longobardo LM, Oliva-Moreno J, Hidalgo-Vega Á, et al. Economic valuation and determinants of informal care to disabled people with chronic obstructive pulmonary disease (COPD). BMC Health Serv Res. 2015;15:101.

27. Pérez M, Puig-Peiró R, Aceituno S, et al. Impacto económico de las exacerbaciones agudas en EPOC desde la perspectiva del SNS español. Rev Patol Respir. 2016;19(3):88-95. Spanish.

28. Salvador-Carulla L, Bendeck M, Fernández A, et al. Costs of depression in Catalonia (Spain). J Affect Disord. 2011;132(1-2):130-138.

29. American Diabetes Association. Economic costs of diabetes in the U.S. in 2012. Diabetes Care. 2013;36(4):1033-1046. 
30. Schofield D, Shrestha RN, Cunich MM, et al. The costs of diabetes among Australians aged 45-64 years from 2015 to 2030: projections of lost productive life years (PLYs), lost personal income, lost taxation revenue, extra welfare payments and lost gross domestic product from Health\&WealthMOD2030. BMJ Open. 2017;7(1):e013158.

31. Lopez-Bastida J, Oliva-Moreno J, Perestelo-Perez L, Serrano-Aguilar P. The economic costs and health-related quality of life of people with HIV/AIDS in the Canary Islands, Spain. BMC Health Serv Res. 2009; 9(1):55.
32. Kobelt G, Sobocki P, Mulero J, Gratacos J, Pocovi A, CollantesEstevez E. The burden of ankylosing spondylitis in Spain. Value Health. 2008;11(3):408-415.

33. Oliva J, Jorgensen N, Rodríguez JM. Carga socioeconómica de la insuficiencia cardiaca: revisión de los estudios de coste de la enfermedad. Pharmacoecon Span Res Artic. 2010;7(2):68-79. Spanish.

34. Kobelt G, Berg J, Atherly D, Hadjimichael O. Costs and quality of life in multiple sclerosis: a cross-sectional study in the United States. Neurology. 2006;66(11):1696-1702. 


\section{Supplementary material}

Table SI Unit prices of resources related to COPD

\begin{tabular}{|c|c|c|}
\hline Resources & Euros (2015) & Reference \\
\hline \multicolumn{3}{|l|}{ Visits to the pulmonology specialist } \\
\hline \multicolumn{3}{|l|}{ First visit } \\
\hline Section I & 201.82 & Section I: HA of Badajoz' \\
\hline Section 2 & 183.57 & Section 2: HA of Cáceres' \\
\hline Section 3 & 145.69 & $\begin{array}{l}\text { Section 3: HA of Don Benito-Villanueva, } \\
\text { Mérida, Llerena-Zafra, and Plasencia' }\end{array}$ \\
\hline Section 4 & 131.13 & Section 4: HA of Navalmoral and Coria' \\
\hline \multicolumn{3}{|l|}{ Subsequent visit } \\
\hline Section I & 121.09 & Section I: HA of Badajoz' \\
\hline Section 2 & 110.15 & Section 2: HA of Cáceres' \\
\hline Section 3 & 87.42 & $\begin{array}{l}\text { Section 3: HA of Don Benito-Villanueva, } \\
\text { Mérida, Llerena-Zafra, and Plasencia' }\end{array}$ \\
\hline Section 4 & 78.68 & Section 4: HA of Navalmoral and Coria' \\
\hline \multicolumn{3}{|l|}{ Medical tests } \\
\hline Blood analysis & 72.45 & 1 \\
\hline Spirometry with bd test & 84.16 & 1 \\
\hline Spirometry without bd test & 42.08 & 1 \\
\hline Alpha-I antitrypsin & 10.29 & Average price $2-4$ \\
\hline Chest X-ray & 17.08 & 1 \\
\hline CAT & 93.97 & 1 \\
\hline Gasometry & 7.88 & 1 \\
\hline \multicolumn{3}{|l|}{ Other medical tests } \\
\hline AgI Legionella urine & 21.03 & 1 \\
\hline Antibiogram & 37.58 & 1 \\
\hline Diffusing capacity & 133.17 & 1 \\
\hline Co-oximetry & 11.60 & 5 \\
\hline Sputum culture & 37.58 & 1 \\
\hline Streptococcus pneumoniae culture & 23.20 & 1 \\
\hline 6-minute walk test & 126.66 & 1 \\
\hline Electrocardiogram & 30.24 & 1 \\
\hline Echocardiogram & 168.83 & 1 \\
\hline Abdominal ultrasound & 54.79 & 1 \\
\hline $\mathrm{FeNO}$ & 17.19 & 2 \\
\hline Pulmonary scintigraphy & 272.49 & 1 \\
\hline Thyroid hormones & 26.12 & 1 \\
\hline Cardiorespiratory polygraphy & 192.79 & Average price $2,4,6,7$ \\
\hline Oxygen saturation/pulsometry & 2.81 & 4,5 \\
\hline \multicolumn{3}{|l|}{ Visits to the emergency room } \\
\hline Emergency consultation in primary care & 54.88 & 1 \\
\hline Emergency consultation in hospital care & 218.61 & 1 \\
\hline \multicolumn{3}{|l|}{ Use of ambulance } \\
\hline Use of non-assisted emergency health transport & 273.23 & Average price $4,5,8-15$ \\
\hline Use of emergency ambulance (medicalized) in situ & $1,076.46$ & 1 \\
\hline \multicolumn{3}{|l|}{ Hospital admissions } \\
\hline GRD 85: pleural effusion with CC & $4,533.10$ & 16 \\
\hline GRD 88: COPD & $2,652.45$ & 16 \\
\hline
\end{tabular}

(Continued) 
Table SI (Continued)

\begin{tabular}{|c|c|c|}
\hline Resources & Euros (20I5) & Reference \\
\hline GRD 89: simple pneumonia and pleuritis age $>17$ with CC & $3,581.46$ & 16 \\
\hline GRD 99: respiratory signs and symptoms with CC & $3,221.03$ & 16 \\
\hline GRD I0I: other respiratory system diagnoses with CC & $3,495.95$ & 16 \\
\hline GRD I43: chest pain & $2,338.61$ & 16 \\
\hline \multicolumn{3}{|l|}{ Home oxygen therapy } \\
\hline One day of use & 3.74 & $\begin{array}{l}\text { Weighted average according to percentage } \\
\text { of use of each type of home oxygen therapy }{ }^{17}\end{array}$ \\
\hline \multicolumn{3}{|l|}{ Stay in housing or residential center } \\
\hline One month of stay in nursing home & 732.91 & 1 \\
\hline \multicolumn{3}{|l|}{ Day care center } \\
\hline Care/year/user & $6,145.35$ & 18 \\
\hline \multicolumn{3}{|l|}{ Professional care at home } \\
\hline One hour of formal care & 6.14 & 18 \\
\hline \multicolumn{3}{|l|}{ Informal care } \\
\hline One hour of informal care & 5.08 & $\begin{array}{l}\text { Equivalent to I hour of minimum } \\
\text { interprofessional salary for domestic } \\
\text { employees, as it is not specialized care }{ }^{19}\end{array}$ \\
\hline \multicolumn{3}{|l|}{ Wage for every hour worked } \\
\hline \multicolumn{3}{|l|}{ Females } \\
\hline Occupation high & 16.88 & Large occupation groups $1-3^{20,21}$ \\
\hline Occupation medium & 9.90 & Large occupation groups $4-7^{20,21}$ \\
\hline Occupation low & 9.38 & Large occupation groups 8 and $9^{20,21}$ \\
\hline All occupations & 11.81 & 20,21 \\
\hline \multicolumn{3}{|l|}{ Males } \\
\hline Occupation high & 20.05 & Large occupation groups $1-3^{20,21}$ \\
\hline Occupation medium & 11.45 & Large occupation groups $4-7^{20,21}$ \\
\hline Occupation low & 9.67 & Large occupation groups 8 and $9^{20,21}$ \\
\hline All occupations & 13.39 & 20,21 \\
\hline
\end{tabular}

Abbreviations: HA, health area; bd, bronchodilator; CC, complications and/or comorbidities; FeNO, fractional exhaled nitric oxide; GRD, related groups by diagnosis; Ref, reference; CAT, computerized axial tomography.

\section{References}

1. Extremadura. Resolución de 17 de febrero de 2015, del Consejero, por la que se publican las tarifas actualizadas de las tasas y precios públicos de la Comunidad Autónoma de Extremadura, en virtud de lo dispuesto en la Ley de Presupuestos Generales de la Comunidad Autónoma de Extremadura para el 2015. DOE núm. 36. 2015. Available from: http://doe.gobex.es/ pdfs/doe/2015/360o/15060397.pdf. Accessed August 5, 2016.

2. Comunitat Valenciana. Decreto Legislativo 1/2005, de 25 de febrero, del Consell de la Generalitat, por el que se aprueba el Texto Refundido de la Ley de Tasas de la Generalitat. Ejercicio 2014. DOCV núm. 4971. 2014. Available from: http://www.san.gva.es/documents/151744/2847194/ LEY+DE+TASAS+2014.pdf. Accessed August 23, 2016.

3. País Vasco. Acuerdo de 23 de febrero de 2015, del Consejo de Administración del Ente Público Osakidetza-Servicio vasco de salud, por el que se aprueban las tarifas por prestación de servicios sanitarios y docentes a terceros obligados al pago durante el ejercicio 2015. BOPV núm. 2015042. 2015. Available from: http://www.irekia.euskadi.eus/es/ orders/201501017?track=1. August 31, 2016.

4. Illes Balears. Resolución del Director General del Servei de Salut de modificación del anexo I de la Orden de la Conselleria de Salut i Consum de 22 de diciembre de 2006. BOIB núm. 89. 2014. Available from: http:// www.caib.es/eboibfront/es/2014/8339/542720/resolucion-del-directorgeneral-del-servei-de-salu. August 23, 2016.
5. Catalunya. Orden SLT/30/2013, de 20 de febrero, por la que se aprueban los precios públicos del Servicio Catalán de la Salud. DOGC núm. 6323. 2013. Available from: http://www.ias.cat/adjunts/files/1286875(1).pdf Accessed July 21, 2016.

6. Castilla-La Mancha. Resolución de 02/12/2009, de la Dirección Gerencia, sobre las condiciones económicas aplicables en el año 2010 a la prestación de servicios concertados de asistencia sanitaria, en el ámbito de gestión del SESCAM. DOCM núm. 9. 2010. Available from: http://docm.castillalamancha.es/portaldocm/descargarArchivo. do? ruta $=2010 / 01 / 15 /$ pdf $/ 2010 \_152 . p d f \&$ tipo=rutaDocm. Accessed August 23, 2016.

7. Aragón. Orden de 21 de enero de 2010, de la Consejera de Salud y Consumo, por la que se modifica el anexo I de la Orden de 27 de abril de 2007, por la que se regula la acción concertada en materia de prestaciones de servicios sanitarios. BOA núm. 29. 2010. Available from: http://www. boa.aragon.es/cgi-bin/EBOA/BRSCGI?CMD=VEROBJ\&MLKOB= 501027143535. Accessed August 23, 2016.

8. Navarra [webpage on the Internet]. Resolución $882 / 2010$, de 3 de mayo, del Director Gerente del Servicio Navarro de Salud-Osasunbidea, por la que se actualizan las tarifas por prestación de servicios en los centros y establecimientos asistenciales del Servicio Navarro de Salud-Osasunbidea. BON núm. 71. 2010. Available from: http://www. navarra.es/home_es/Actualidad/BON/Boletines/2010/71/Anuncio-10/. August 23, 2016. 
9. La Rioja. Orden 17/2014, de 16 de noviembre de 2014, de la Consejería de Administración Pública y Hacienda, por la que se establece y regula el precio público por los servicios sanitarios prestados a particulares en los centros del Servicio Riojano de Salud. BOR núm. 156. 2014. Available from: http://ias1.larioja.org/boletin/Bor_Boletin_visor_ Servlet?referencia=1902409-1-PDF-486979. August 23, 2016.

10. Aragón. Resolución de 30 de julio de 2012, de la Dirección de Gerencia del Servicio Aragonés de Salud, sobre revisión de las tarifas a aplicar por la prestación de servicios sanitarios a terceros obligados al pago o a usuarios sin derecho a asistencia sanitaria en la Comunidad Autónoma de Aragón. BOA núm. 156. 2012. Available from: http://benasque. aragob.es:443/cgi-bin/EBOA/BRSCGI?CMD=VEROBJ\&MLKOB= 686810581515. Accessed July 21, 2016.

11. Comunidad de Madrid. Orden 731/2013, de 6 de septiembre, del Consejero de Sanidad, por la que se fijan los precios públicos por la prestación de los servicios y actividades de naturaleza sanitaria de la Red de Centros de la Comunidad de Madrid. BOCM núm. 215. 2013. Available from: http://w3.bocm.es/boletin/CM_Orden_BOCM/2013/09/10/ BOCM-20130910-1.PDF. August 23, 2016.

12. Castilla y León. DECRETO 83/2013, de 26 de diciembre, por el que se actualizan los precios públicos de la Comunidad de Castilla y León y la tasa por actuaciones administrativas relativas a actividades agrícolas. BOCYL núm. 249. 2013. Available from: http://bocyl.jcyl.es/ boletines/2013/12/30/pdf/BOCYL-D-30122013-5.pdf. Accessed July 21, 2016.

13. Castilla-La Mancha. Orden de 17/11/2014, de la Consejería de Sanidad y Asuntos Sociales, por la que se establecen los precios públicos de la asistencia sanitaria y de los servicios prestados en la red de centros sanitarios dependientes del Servicio de Salud de Castilla-La Mancha. DOCM núm. 226. 2014. Available from: http://docm.castillalamancha. es/portaldocm/descargarArchivo.do?ruta=2014/11/21/pdf/2014_15022. pdf\&tipo=rutaDocm. August 23, 2016.

14. Canarias. Resolución de 30 de marzo de 2015, de la Directora, por la que se modifica la cuantía de los precios públicos de servicios sanitarios previstos en el Decreto 81/2009, de 16 de junio, que establece los precios públicos de los servicios sanitarios prestados por el Servicio Canario de la Salud y fija sus cuantías. BOC núm. 70. 2015. Available from: http://sede. gobcan.es/boc/boc-a-2015-070-1674.pdf. Accessed August 26, 2016.
15. Cantabria. Orden SAN/12/2011, de 20 de abril, por la que se fijan las cuantías de los precios públicos de los Servicios Sanitarios prestados por el Servicio Cántabro de Salud. BOC núm. 85. 2011. Available from: http://www.saludcantabria.es/uploads/pdf/consejeria/boletinesCVEordendeprecios.pdf. August 23, 2016.

16. Ministerio de Sanidad, Servicios Sociales e Igualdad. Norma de referencia: Norma Ministerio APv27.0. 2010. Available from: http:// www.msssi.gob.es/estadEstudios/estadisticas/docs/SNS2011_PESOS_ COSTES_AP27_DEF.pdf. Accessed August 8, 2016.

17. Fenin. Estudio sobre la eficiencia y los beneficios de las terapias respiratorias domiciliarias. 2011. Available from: http://panelfenin.es/ uploads/fenin/documento_estudios/pdf_documento_11.pdf. Accessed August 5, 2016.

18. Fernández Muñoz J. Informe 2014. Las personas mayores en España. Madrid: Ministerio de Sanidad, Servicios Sociales e Igualdad; 2015. Available from: http:/www.imserso.es/InterPresent1/groups/ imserso/documents/binario/22029_info2014pm.pdf. Accessed August 8, 2016.

19. España. Real Decreto $1106 / 2014$, de 26 de diciembre, por el que se fija el salario mínimo interprofesional para 2015. BOE núm. 313. 2014. Available from: http:/www.boe.es/diario_boe/txt.php?id=BOE-A2014-13518. Accessed August 10, 2016.

20. Instituto Nacional de Estadística. Resultados Nacionales y por CCAA: Ganancia por hora normal de trabajo Sexo y ocupación (2013). Encuesta anual de estructura salarial. Serie 2008-2013. 2013. Available from: http://www.ine.es/jaxi/Datos.htm?path=/t22/p133/cno11/serie/ 10/\&file=04002.px. Accessed August 8, 2016.

21. Instituto Nacional de Estadística. Número medio de horas efectivas semanales trabajadas por todos los ocupados (hayan o no trabajado en la semana) por situación profesional, sexo y ocupación (empleo principal). Encuesta de Población Activa 2015T3. 2015. Available from: http://www.ine.es/jaxiT3/Tabla.htm?t=4318\&L=0. Accessed August 8, 2016.
International Journal of COPD

\section{Publish your work in this journal}

The International Journal of COPD is an international, peer-reviewed journal of therapeutics and pharmacology focusing on concise rapid reporting of clinical studies and reviews in COPD. Special focus is given to the pathophysiological processes underlying the disease, intervention programs, patient focused education, and self management protocols.

\section{Dovepress}

This journal is indexed on PubMed Central, MedLine and CAS. The manuscript management system is completely online and includes a very quick and fair peer-review system, which is all easy to use. Visit http://www.dovepress.com/testimonials.php to read real quotes from published authors. 